\title{
A study on relationship between the information of cash value added and return of stocks: An empirical investigation on accounting profit, free cash flow and Tobin's $Q$
}

\author{
Somayeh Sadeghi Moghaddam $^{\mathrm{a}^{*}}$ and Abbas Talebbeydokhti ${ }^{\mathrm{b}}$
}

${ }^{a}$ Department of Accounting, Science \& Research Branch, Islamic Azad University, Fars, Iran

${ }^{b}$ Department of Accounting, Gachsaran Branch, Islamic Azad University, Gachsaran, Iran

CHRON I CLE ABSTRACT

Article history:

Received Feb 28, 2013

Received in revised format

19 September 2013

Accepted 23 October 2013

Available online

November 202013

Keywords:

Cash value added

Accounting profit

Free cash flow

Stock return

Tobin's $Q$
This paper presents an empirical investigation to the study the effects of various factors such as free cash flow, earnings, Tobin's Q on predicting stock performance on Tehran Stock Exchange (TSE) over the period 2005-2012. The study is performed on data from different industries including basic metals, cements, chemical, auto industry, etc. The proposed model gathers the necessary data from TSE and using various regression models, the study has determined that there was a meaningful relationship between cash value added, Earnings and Tobin's Q when the level of significance was five percent but there was not any meaningful relationship between stock earnings and free cash flow.

\section{Introduction}

During the past few years, there have been tremendous efforts to learn more about the effect of various factors on predicting stock performance (Dechow, 1994; Dechow \& Dichev, 2002; Hirshleifer et al., 2009; Venanzi, 2012; Gandellini et al., 2013). Maditinos et al. (2009), for instance, investigated the explanatory power of two value-based performance measurement models, Economic Value Added (EVA) and shareholder value added (SVA), compared with three traditional accounting performance measures including earnings per share (EPS), return on investment (ROI), and return on equity (ROE), in describing stock market returns in the Athens Stock Exchange (ASE). They reported that stock market returns were more closely associated with EPS than with EVA or other performance measures but suggested that the pairwise combination of EVA with EPS could increase significantly the explanatory power in explaining stock market returns.

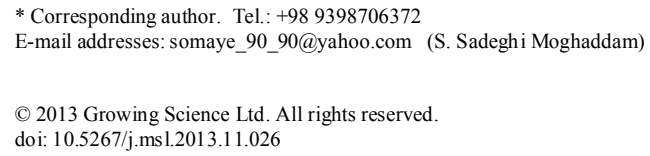


Fernandez (2001) reported that EVA and cash value added could not be considered as good measure for shareholder value creation. Valahzaghard and Bakhsh (2013) performed a study on relationship between abnormal accruals and future profitability on Tehran Stock Exchange. They reported that while there were no meaningful relationship between firm size, capital expenditure, earnings quality and earning forecasted error on one side and future earnings, there was a significance relationship between ratio of book value to equity as well as market leverage and future earnings.

Khaksarian (2013) performed a study on relationship between earnings response coefficient and earnings management. The study applied Johns's model (Jones, 1991) to investigate the behavior of earnings management. In addition, the proposed study used Ohlson's model (Ohlson, 1995) to estimate earnings response coefficient. The study gathered the necessary information from 250 firms from TSE market over the period 2006-2012 and they reported that there was a negative and meaningful relationship between earnings response coefficient and earnings management. Banimahd and Jalali Aliabadi (2013) performed a study on relationship between earnings management and operating cash flows management and discussed the relationship based on some regression analysis.

Maranjory et al. (2013) investigated the role of discretionary accruals in the earnings management of Iranian firms. There were two hypotheses associated with this study on the relationship between income smoothness and discretionary accruals and the proposed study was implemented on selected firms from Tehran Stock Exchange. The result of the first hypothesis revealed the relationship between earnings smoothness and discretionary accruals variables. It means that discretionary accruals leads to the converse relationship among discretionary accruals variation and current and future cash flow. The result of the second hypothesis indicated that the firms with high variation in Iran utilized more discretionary accruals compared with the firms with lower variation.

\section{The proposed study}

This paper presents an empirical investigation to the study the effects of various factors such as free cash flow, earnings, Tobin's Q on predicting stock performance on Tehran Stock Exchange (TSE) over the period 2005-2012. We first present details of the hypotheses of the survey.

\subsection{Hypothesis}

The proposed study of this paper considers three main hypotheses as follows,

First main hypothesis: There is a meaningful relationship between return of stock $(\mathrm{R})$ as dependent variable and Cash value added (CVA), free cash flow (FCF), Earnings and Tobin's Q (Qs).

The first main hypothesis consists of the following four sub-hypotheses,

1. There is a meaningful relationship between CVA and stock return.

2. There is a meaningful relationship between Earnings and stock return.

3. There is a meaningful relationship between Tobin's Q and stock return.

4. There is a meaningful relationship between FCF and stock return.

The following linear regression models are used for the proposed study of this paper,

$$
\begin{aligned}
& R_{i t}=\beta_{0}+\beta_{1} C V A_{i t}+\varepsilon_{i t}, \\
& R_{i t}=\beta_{0}+\beta_{1} \text { Earning }_{i t}+\varepsilon_{i t},
\end{aligned}
$$




$$
\begin{aligned}
& R_{i t}=\beta_{0}+\beta_{1} Q s_{i t}+\varepsilon_{i t}, \\
& R_{i t}=\beta_{0}+\beta_{1} F C F_{i t}+\varepsilon_{i t} .
\end{aligned}
$$

Second main hypothesis: CVA provides better information of earnings compared with Earnings, Tobin's Q and FCF.

The second hypothesis also consists of the following three sub-hypotheses,

1. CVA provides better information of stock return than Earning does.

2. CVA provides better information of stock return than Tobin's Q does.

3. CVA provides better information of stock return than FCF does.

Third main hypothesis: CVA provides richer information of earnings compared with Earnings, Tobin's Q and FCF.

The second hypothesis also consists of the following three sub-hypotheses,

1. CVA provides richer information of stock return than Earning does.

2. CVA provides richer information of stock return than Tobin's Q does.

3. CVA provides richer information of stock return than FCF does.

To examine the second and the third hypothesis of the survey, we use the following regression models,

$$
\begin{aligned}
& R_{i t}=\beta_{0}+\beta_{1} C V A_{i t}+\beta_{2} \text { Earning }_{i t}+\varepsilon_{i t}, \\
& R_{i t}=\beta_{0}+\beta_{1} C V A_{i t}+\beta_{2} Q s_{i t}+\varepsilon_{i t}, \\
& R_{i t}=\beta_{0}+\beta_{1} C V A_{i t}+\beta_{2} F C F_{i t}+\varepsilon_{i t}, \\
& R_{i t}=\beta_{0}+\beta_{1} \text { Earning }_{i t}+\beta_{2} Q s_{i t}+\varepsilon_{i t}, \\
& R_{i t}=\beta_{0}+\beta_{1} \text { Earning }_{i t}+\beta_{2} F C F_{i t}+\varepsilon_{i t}, \\
& R_{i t}=\beta_{0}+\beta_{1} Q s_{i t}+\beta_{2} F C F_{i t}+\varepsilon_{i t}, \\
& R_{i t}=\beta_{0}+\beta_{1} C V A_{i t}+\beta_{2} E_{i t}+\beta_{3} Q S_{i t}+\beta_{4} F C F_{i t}+\varepsilon_{i t} .
\end{aligned}
$$

\subsection{Dependent variable}

Stock return is the independent variable of this survey and it is calculated as follows,

Stock return $=\frac{\text { Stock price of the end of the year }- \text { Stock price of the beginning of the year }+ \text { dividend paid }+ \text { prize share value }+ \text { Warrant value }}{\text { Stock price of the end of the year }}$

\subsection{Independent variables}

Cash value added (VCA) is the first independent variable of the survey and it is calculated as the earnings after tax minus the cost of capital. Free Cash Flow (FCF) is calculated as a difference between non-interest current assets and non-interest current liabilities. Finally, Tobin's Q is calculated as follows, 
Tobin's Q $=\frac{\text { COMVAL }+ \text { PREFVAL }+ \text { SBOND }+ \text { STDEBT }}{\text { SRC }}$,

where COMVAL is the value of common shares, PREFVAL denotes the value of preferred shares, $S B O N D$ is the long term liabilities and $S T D E B T$ is the short term liabilities.

\subsection{The population of the survey}

The survey includes all stocks whose share were accepted on Tehran Stock Exchange in one of six groups of basic metals, cement, auto-industry, chemical and other metals over the period 2005-2012. There are four criteria for selection of the firms. First, they must be accepted to exchange prior to year 2005, there must be no long interruption on stock trade, no fiscal year change and finally all necessary financial information must be available.

\subsection{Fixed effect versus random effect}

The next step is to determine whether we should choose random effect or fixed effect and this could be verified using F-Limer test. Table 1 demonstrates the summary of our survey.

\section{Table 1}

The summary of testing fixed/random effect

\begin{tabular}{ccccc}
\hline Model & F-value & df & Sig. & Result \\
\hline 1 & 0.8383 & 93.657 & 0.8555 & Random effect \\
2 & 0.7515 & 93.657 & 0.957 & Random effect \\
3 & 0.9015 & 93.656 & 0.73 & Random effect \\
4 & 0.9045 & 93.657 & 0.7231 & Random effect \\
5 & 0.7254 & 93.656 & 0.973 & Random effect \\
6 & 0.8856 & 93.655 & 0.7652 & Random effect \\
7 & 0.8528 & 93.656 & 0.8303 & Random effect \\
8 & 0.8774 & 93.655 & 0.7824 & Random effect \\
9 & 0.7439 & 93.656 & 0.9623 & Random effect \\
10 & 0.8824 & 93.655 & 0.7719 & Random effect \\
11 & 0.8336 & 93.653 & 0.863 & Random effect \\
\hline
\end{tabular}

As we can observe from the results of Table 1, we need to choose random effect for regression analysis.

\section{The results}

In this section, we present details of our findings on testing different hypotheses of this survey. We have applied regression analysis on Eqs. (1-4) and Table 2 demonstrates the summary of our findings.

\section{Table 2}

The summary of testing the first hypothesis

\begin{tabular}{ccccccc}
\hline Model & Independent variable & Coefficient & t-student & P-value & $\mathrm{R}^{2}$ & Adjusted R $^{2}$ \\
\hline 1 & CVA & 0.4114 & 2.4161 & 0.0159 & 0.0077 & 0.0064 \\
2 & Earnings & 0.4103 & 4.3574 & 0.000 & 0.0246 & 0.0233 \\
3 & Qs & 0.1491 & 6.1274 & 0.000 & 0.0477 & 0.0464 \\
4 & FCF & -0.1099 & -0.9890 & 0.323 & 0.0013 & -0.00002 \\
\hline
\end{tabular}

As we can observe from the results of Table 2, there is meaningful relationship between CVA, Earnings and Qs when the level of significance is five percent. Therefore, we can confirm the first three sub-hypotheses associated with the first main hypothesis but there is not any meaningful relationship between stock earnings and FCF so we cannot confirm the last hypothesis. In addition, the ratio of Earnings maintains a higher value than CVA, which means we can confirm the second 
main hypothesis. Finally, to examine the third main hypothesis of the survey, we perform regression techniques on Eqs. (5-11) and Table 3 demonstrates the results of our survey.

Table 3

The summary of regression results for the third hypothesis

\begin{tabular}{|c|c|c|c|c|c|c|c|}
\hline Model & & Intercept & CVA & Earning & Qs & FCF & $\mathrm{R}^{2}$ \\
\hline \multirow{3}{*}{5} & Value & 0.1286 & 0.3272 & 0.3882 & & & \multirow{3}{*}{0.0295} \\
\hline & t-student & 5.4822 & 1.9274 & 4.1000 & & & \\
\hline & Sig. & 0.000 & 0.0543 & 0.0000 & & & \\
\hline \multirow{3}{*}{6} & Value & -0.227 & 0.2533 & & 0.1431 & & \multirow{3}{*}{0.0505} \\
\hline & t-student & -0.5781 & 1.4991 & & 5.8102 & & \\
\hline & Sig. & 0.5633 & 0.1342 & & 0.0000 & & \\
\hline \multirow{3}{*}{7} & Value & 0.1869 & 0.4264 & & & -0.1306 & \multirow{3}{*}{0.0095} \\
\hline & t-student & 8.2522 & 2.4978 & & & -1.1762 & \\
\hline & Sig. & 0.0000 & 0.0127 & & & 0.2399 & \\
\hline \multirow{3}{*}{8} & Value & -0.0182 & & 0.2064 & 0.1262 & & \multirow{3}{*}{0.0528} \\
\hline & t-student & -0.4624 & & 2.0126 & 4.7115 & & \\
\hline & Sig. & 0.6439 & & 0.0445 & 0.0000 & & \\
\hline \multirow{3}{*}{9} & Value & 0.1500 & & 0.4555 & & -0.2312 & \multirow{3}{*}{0.0301} \\
\hline & t-student & 6.1964 & & 4.7202 & & -2.0537 & \\
\hline & Sig. & 0.0000 & & 0.0000 & & 0.0403 & \\
\hline \multirow{3}{*}{10} & Value & -0.0142 & & & 0.1582 & -0.2335 & \multirow{3}{*}{0.0534} \\
\hline & t-student & -0.3608 & & & 6.4188 & -2.1214 & \\
\hline & Sig. & 0.7183 & & & 0.0000 & 0.0342 & \\
\hline \multirow{3}{*}{11} & Value & -0.0047 & 0.2506 & 0.2434 & 0.1275 & -0.2863 & \multirow{3}{*}{0.0635} \\
\hline & t-student & -0.1193 & 1.4879 & 2.3448 & 4.7267 & -2.5705 & \\
\hline & Sig. & 0.9051 & 0.1372 & 0.0193 & 0.0000 & 0.0103 & \\
\hline
\end{tabular}

We now are able to determine the incremental value added of each pairs of components, which are summarized in Table 4 as follows,

Table 4

The summary of incremental values of each pairs of ratios

\begin{tabular}{cccc}
\hline CVA/Earning & Earning/CVA & CVA/Qs & Qs/CVA \\
\hline 0.0049 & 0.0218 & 0.0028 & 0.0428 \\
\hline CVA/FCF & FCF/CVA & Earning/Qs & Qs/Earning \\
\hline 0.0082 & 0.0018 & 0.0051 & 0.0282 \\
Earning/FCF & FCF/Earning & Qs/FCF & FCF/Qs \\
\hline 0.0288 & 0.0055 & 0.0521 & 0.0057 \\
\hline
\end{tabular}

Based on the values presented in Table 4, we may now examine the last three sub-hypotheses of the survey, which were associated with the third hypothesis of the survey. The first sub-hypothesis studies CVA is compared against earnings for measuring the power of predicting stock performance. According to Table 4, Earning represents a value of 0.0218 , which is greater than the value of 0.0049 measured for CVA. Therefore, the first sub-hypothesis of the survey is not confirmed. The second sub-hypothesis of the survey considers the CVA (0.0028) against Qs (0.0428) and based on the results we cannot confirm the second sub-hypothesis. Finally, the third sub-hypothesis of the survey considers the CVA (0.0082) against FCF (0.0018) and based on the results we can confirm the last sub-hypothesis.

\section{Conclusion}

In this paper, we have presented an empirical investigation to the study the effects of various factors on predicting stock performance. The proposed model of this paper has gathered the necessary data 
from Tehran Stock Exchange and using various regression models, the study has determined that there was a meaningful relationship between cash value added, Earnings and Tobin's Q when the level of significance is five percent but there was not any meaningful relationship between stock earnings and free cash flow.

\section{Acknowledgement}

The authors would like to thank the anonymous referees for constructive comments on earlier version of this paper.

\section{References}

Banimahd, B., \& Jalali Aliabadi, M. (2013). A study on relationship between earnings management and operating cash flows management: Evidence from Tehran Stock Exchange. Management Science Letters, 3(6), 1677-1688.

Dechow, P. M. (1994). Accounting earnings and cash flows as measures of firm performance: The role of accounting accruals. Journal of accounting and economics, 18(1), 3-42.

Dechow, P. M., \& Dichev, I. D. (2002). The quality of accruals and earnings: The role of accrual estimation errors. The accounting review, 77(s-1), 35-59.

Fernandez, P. (2001). EVA and cash value added do NOT measure shareholder value creation. Available at SSRN 270799.

Gandellini, G., Pezzi, A., \& Venanzi, D. (2013). Financial Performance and Sustainability of Strategy. In Strategy for Action-II (pp. 101-117). Springer Milan.

Hirshleifer, D., Hou, K., \& Teoh, S. H. (2009). Accruals, cash flows, and aggregate stock returns. Journal of Financial Economics, 91(3), 389-406.

Jones, J. J. (1991). Earnings management during import relief investigations. Journal of accounting research, 29(2), 193-228

Khaksarian, F. (2013). A study on relationship between earnings response coefficient and earnings management: Evidence from Tehran Stock Exchange. Management Science Letters, 3(10), 25492554.

Maditinos, D. I., Ševic, Ž., \& Theriou, N. G. (2009). Modelling traditional accounting and modern value-based performance measures to explain stock market returns in the Athens Stock Exchange (ASE). Journal of Modelling in Management, 4(3), 182-201.

Maranjory, M., Alikhani, R., Zabihzadeh, A \& Sepehri, P. (2013). The role of discretionary accruals in earnings management: Evidence from Tehran Stock Exchange. Management Science Letters, 3(9), 2399-2404.

Ohlson, J. A. (1995). Earnings, book values, and dividends in equity valuation. Contemporary Accounting Research, 11(2), 661-687

Valahzaghard, M \& Bakhsh, S. (2013). A study on relationship between abnormal accruals and future profitability: Evidence from Tehran Stock Exchange. Management Science Letters, 3(11), 28532858.

Venanzi, D. (2012). Springerbriefs In Business: Financial Performance Measures and Value Creation: The State of the Art. Springer. 